\title{
Effects of Asian Dust Particles on the Early-Stage Antigen-Induced Immune Response of Asthma in NC/Nga Mice
}

\author{
Jun Kurai ${ }^{1}$, Masanari Watanabe ${ }^{1, *}$, Hiroyuki Sano ${ }^{2}$, Degejirihu Hantan ${ }^{1}$, Yuji Tohda ${ }^{2}$ \\ and Eiji Shimizu ${ }^{1}$ \\ 1 Department of Respiratory Medicine and Rheumatology, Faculty of Medicine, Tottori University, \\ 36-1 Nishi-cho, Yonago 683-8504, Japan; junkurajun@gmail.com (J.K.); \\ degujirefu@med.tottori-u.ac.jp (D.H.); eiji@med.tottori-u.ac.jp (E.S.) \\ 2 Department of Respiratory Medicine and Allergology, Kinki University, 377-2 Ohnohigashi, \\ Osakasayama 589-0014, Japan; hsano@med.kindai.ac.jp (H.S.); tohda@med.kindai.ac.jp (Y.T.) \\ * Correspondence: watanabm@grape.med.tottori-u.ac.jp; Tel.: +81-859-38-6537; Fax: +81-859-38-6539 \\ Academic Editor: Paul B. Tchounwou \\ Received: 6 October 2016; Accepted: 14 November 2016; Published: 16 November 2016
}

\begin{abstract}
Asian dust (AD) can aggravate airway inflammation in asthma, but the association between $\mathrm{AD}$ and the development of asthma remains unclear. This study aimed to investigate the effects of $\mathrm{AD}$ on the early stage of antigen sensitization using a mouse model of asthma, as well as the role of leukotrienes (LTs) in antigen-induced airway inflammation potentiated by AD particles. NC/Nga mice were co-sensitized by intranasal instillation of AD particles and/or Dermatophagoides farinae (Df) for five consecutive days. Df-sensitized mice were stimulated with an intranasal Df challenge at seven days. Mice were treated with the type 1 cysteinyl LT $\left(\mathrm{CysLT}_{1}\right)$ receptor antagonist orally $4 \mathrm{~h}$ before and $1 \mathrm{~h}$ after the allergen challenge. At $24 \mathrm{~h}$ post-challenge, the differential leukocyte count, inflammatory cytokines, and LTs in bronchoalveolar lavage fluid were assessed, and airway inflammation was evaluated histopathologically. AD augmented neutrophilic and eosinophilic airway inflammation with increased CysLTs and dihydroxy-LT in a mouse model of asthma. The CysLT ${ }_{1}$ receptor antagonist was shown to attenuate both neutrophilic and eosinophilic airway inflammation augmented by AD. Therefore, exposure to AD may be associated with the development of asthma and LTs may play important roles in airway inflammation augmented by AD.
\end{abstract}

Keywords: airway inflammation; asthma; Asian dust; leukotrienes; NC/Nga mouse model

\section{Introduction}

The health burden of airborne particulate matter (PM) is an important environmental health concern, and a number of studies have demonstrated that airborne PM exposure can increase respiratory and cardiovascular morbidity and mortality [1,2]. Desert sand dust particles are an important component of airborne PM and can have great effects on health over large distances because they can travel far from their source [3,4]. Asian dust (AD) emissions originating from East Asian deserts in Mongolia, Northern China, and Kazakhstan produce the second largest volume of dust emissions worldwide, and account for approximately $20 \%$ of the global total [5]. AD emissions most frequently occur from February to May, although data suggests that they may last until late autumn [5-7]. AD particles are continuously carried to Japan, especially from February to May [6,7]. Numerous epidemiological studies have found that AD emissions have effects on respiratory and cardiovascular morbidity and mortality $[3,8]$. Similarly, AD emissions are associated with asthma exacerbation [9-15]. The role of exposure to airborne PM in the development of asthma remains unclear. Recently, several studies have found that exposure to airborne PM early in life may contribute 
to the development of asthma $[16,17]$. However, no previous study has investigated the association between long-term exposure to AD and the development of asthma.

Leukotrienes (LTs) are a family of eicosanoid inflammatory mediators that are produced from the metabolism of arachidonic acid via the 5-lipoxygenase pathway in various cells (including eosinophils, mast cells, and alveolar macrophages) and in response to airway stimuli [18]. There are two classes of LTs: the cysteinyl LTs (CysLTs), such as $\mathrm{LTC}_{4}, \mathrm{LTD}_{4}$, and LTE ; and the dihydroxy-LTs $\left(\mathrm{LTB}_{4}\right)$ [18]. LTs play important roles in asthma, with each class acting through two structurally divergent $G$ protein-coupled receptors: the type 1 and type 2 CysLT receptors (CysLT 1 and $\mathrm{CysLT}_{2}$ receptors, respectively) $[19,20]$. CysLTs can induce strong bronchoconstriction, eosinophilic inflammation, and mucus secretion [19]. Therefore, the LT receptor antagonist is commonly used in the management of asthma.

In contrast to bronchoconstriction mediators (i.e., the CysLTs), $\mathrm{LTB}_{4}$ is thought to be a pro-inflammatory mediator that is responsible for the recruitment, activation, and survival of leukocytes, including neutrophils and eosinophils [21-24]. Several studies have reported that airborne PM is associated with increased in vivo concentrations of CysLTs [25,26]. In humans, Rabinovitch et al. found that the serum concentrations of $\mathrm{LTE}_{4}$ in children with asthma were significantly associated with the levels of PM in their living areas [27]. However, the roles of $\mathrm{LTB}_{4}$ in asthma-associated airway inflammation augmented by PM are still undefined.

The present study aimed to evaluate the effects of AD on early-stage antigen sensitization using a mouse model of asthma. Furthermore, the concentrations of CysLTs and $\mathrm{LTB}_{4}$ in bronchoalveolar lavage fluid (BALF) were measured to evaluate their roles in antigen-induced airway inflammation potentiated by AD particles. This study also investigated whether a CysLT 1 receptor antagonist could abolish these initial immune responses augmented by $\mathrm{AD}$ particles.

\section{Materials and Methods}

\subsection{Animals}

Specific pathogen-free seven-week-old male NC/Nga mice were purchased from Japan SLC Inc. (Hamamatsu, Japan) and acclimatized for seven days before the start of the study. Animals were kept in a vivarium at a constant temperature of $22^{\circ} \mathrm{C}$ and illumination in $12 \mathrm{~h} \mathrm{light/dark} \mathrm{cycles.} \mathrm{Animals}$ were fed standard animal chow daily and had ad libitum access to drinking water. The experimental protocols were approved by our institutional Animal Care and Use Committee (Faculty of Medicine, Tottori University; protocol number 13-Y-5).

\subsection{Preparation of $A D$ Particles}

Airborne particles were collected in Tottori on AD days during 18-22 March 2013, using a high-volume air sampler (HV-1000R; Shibata Co., Tokyo, Japan) that was fixed on the rooftop of a building. AD particles were separated according to their aerodynamic diameters using five filters ( $<1.1 \mu \mathrm{m}, 1.1-2.0 \mu \mathrm{m}, 2.0-3.3 \mu \mathrm{m}, 3.3-7.0 \mu \mathrm{m}$, and $>7.0 \mu \mathrm{m}$ ), and each filter was dried in a desiccator and weighed before and after sampling. The size distribution of AD particles is primarily $3.3-7.0 \mu \mathrm{m}$, and the AD particles for the present study were selected from the 3.3-7.0 $\mu \mathrm{m}$ filter. The AD particles were sterilized at $121{ }^{\circ} \mathrm{C}$ for $30 \mathrm{~min}$ in an autoclave (Tomy SX-300; Tomy Co., Tokyo, Japan) and stored in a freezer at $-20^{\circ} \mathrm{C}$ to prevent the growth of bacteria and fungi. The AD particles were suspended in normal saline (NS) before being administered to the mice.

\subsection{Experimental Protocol}

NC/Nga mice were sensitized to Dermatophagoides farina (DF; Greer Laboratories Inc., Lenoir, NC, USA), as previously described [28]. After a seven-day acclimatization period, the mice were randomly divided into eight groups ( $n=8$ per group). For sensitization, the mice were anesthetized using isoflurane inhalation and underwent intranasal instillation of Df crude extract in NS (50 $\mu \mathrm{g} / 25 \mu \mathrm{L})$ for 
five consecutive days (days 0-4). Df-sensitized mice were challenged intranasally using Df at seven days after the last Df sensitization (day 11) and sacrificed $24 \mathrm{~h}$ after the Df challenge. In the control group, NS was administered instead of Df sensitization.

To observe the effects of a CysLT 1 receptor antagonist (Pranlukast (Prl); Ono Pharmaceutical Co., Ltd., Osaka, Japan) on airway inflammation induced using AD particles $(0.1 \mathrm{mg} / 25 \mu \mathrm{L}$ of NS), mice were co-sensitized using intranasal instillation of AD particles and/or Df for five consecutive days (days 0-4) (Figure 1). Prl was dissolved in $0.5 \%$ carboxymethylcellulose sodium (CMC) and was administered using a gastric tube. Prl-treated mice received Prl orally ( $25 \mathrm{mg} / \mathrm{kg} /$ day) at $4 \mathrm{~h}$ before the allergen challenge and at $1 \mathrm{~h}$ after the challenge on day 11 . In the control group, $0.5 \% \mathrm{CMC}$ was administered orally in the same manner. The eight groups were as follows: (i) NS/NS mice, which were sensitized and challenged using NS; (ii) NS/NS + Prl mice, which were sensitized and challenged using NS, and treated with Prl; (iii) Df/Df mice, which were sensitized and challenged using Df; (iv) Df/Df + Prl mice, which were sensitized and challenged using Df, and treated with Prl; (v) AD/NS mice, which were sensitized using AD particles and challenged using NS; (vi) AD/NS + Prl mice, which were sensitized using AD particles, challenged using NS, and treated using Prl; (vii) AD + Df/Df mice, which were co-sensitized using Df and AD particles, and challenged using Df; and (viii) $\mathrm{AD}+\mathrm{Df} / \mathrm{Df}+\mathrm{Prl}$ mice, which were co-sensitized using Df and AD particles, challenged using Df, and treated with Prl.

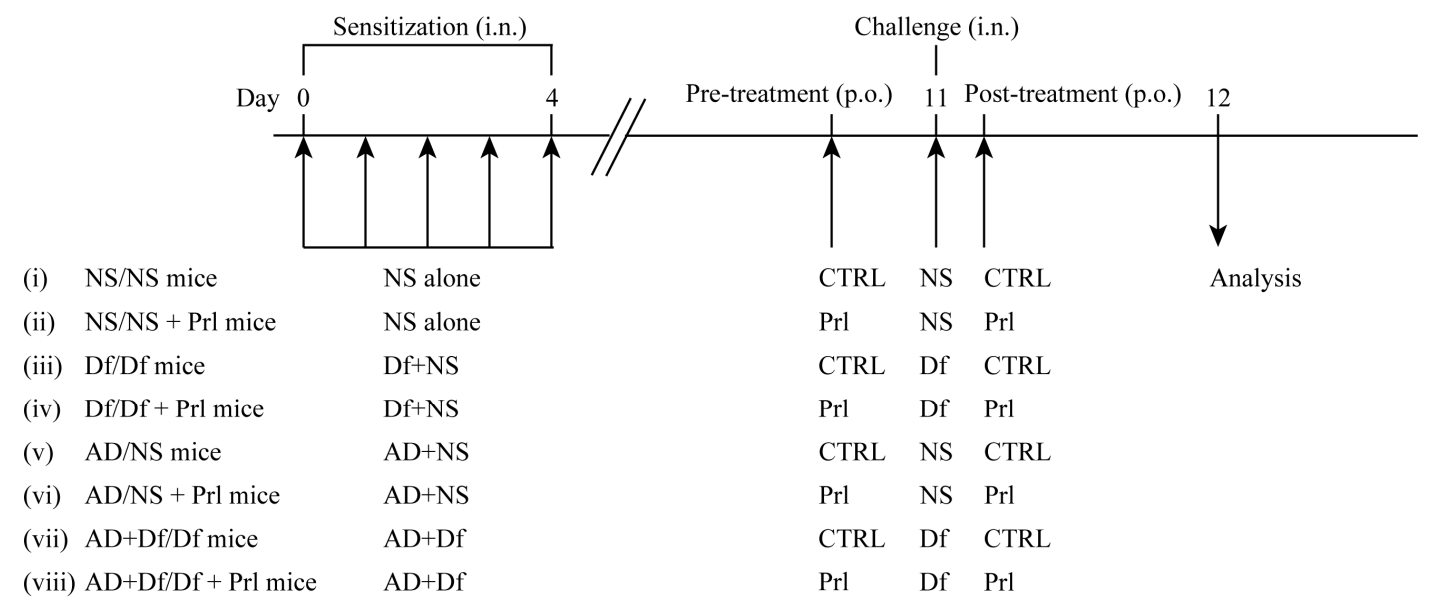

Figure 1. Experimental protocol. NC/Nga mice were sensitized using intranasal (i.n.) installation of a mixture (Asian dust (AD) particles and/or Dermatophagoides farina (Df), or CJ-1 soil and/or Df) for five consecutive days (days 0-4). Pranlukast (Prl)-treated mice received Prl orally ( $25 \mathrm{mg} / \mathrm{kg} /$ day) at $4 \mathrm{~h}$ before the allergen challenge and at $1 \mathrm{~h}$ after the challenge on day 11 . At seven days after the last allergen sensitization, the mice were challenged using the allergen, which was followed by the collection of bronchoalveolar lavage fluid, lung tissue, and serum. Mice were divided into eight groups: normal saline (NS)/NS, NS/NS + Prl, Df/Df, Df/Df + Prl, AD/NS, AD/NS + Prl, AD + Df/Df, and $\mathrm{AD}+\mathrm{Df} / \mathrm{Df}+\operatorname{Prl}$.

\subsection{BALF Procedure}

After the mice were anesthetized using isoflurane, their tracheas were cannulated. BALF was subsequently obtained after five instillations of NS $(1.0 \mathrm{~mL})$ into the lungs, along with gentle handling to maximize BALF recovery. BALF from each mouse was centrifuged at $300 \times g$ for $5 \mathrm{~min}$ at $4{ }^{\circ} \mathrm{C}$. The cell pellet was used for cell counting, and the supernatant was used for cytokine analysis. Total cells diluted in Turk's fluid were counted using a hemocytometer. The differential leukocyte count was performed using microscopic evaluation and quantitative analysis of methanol-fixed cytospin preparations stained using Diff Quick (Thermo Fisher Scientific, Inc., Pittsburgh, PA, USA). 


\subsection{Histological Examination}

Mice were euthanized using a pentobarbital injection. Lungs were inflation-fixed at $25 \mathrm{~cm}$ of water pressure with $10 \%$ formalin for $5 \mathrm{~min}$ and immersed in the same fixative. Tissues were fixed for $24 \mathrm{~h}$ at $4{ }^{\circ} \mathrm{C}$ and processed using standard methods for paraffin-embedded blocks. Fixed lung tissues were embedded in paraffin and sectioned, and each section was stained using hematoxylin and eosin (H\&E).

\subsection{Quantitative Determination of Cytokine, Chemokine, and LT Levels}

Interferon (IFN)- $\gamma$, interleukin (IL)-13, IL-5, IL-6, keratinocyte-derived chemokine (KC/CXCL1), and macrophage inflammatory protein (MIP)-2 (KC/CXCL1 and MIP-2/CXCL2 are murine homologues of human IL-8) levels in BALF were measured using enzyme immunoassay (EIA) kits (R\&D Systems Europe, Abingdon, UK). Granulocyte-macrophage colony stimulating factor (GM-CSF) levels in serum and BALF were measured using EIA kits (R\&D Systems Europe), as were CysLTs and $\mathrm{LTB}_{4}$ levels (Cayman Chemical, Ann Arbor, MI, USA). BALF dilutions were 1:5 for IL-13, IL-5, IL-6, KC/CXCL1, and MIP-2/CXCL2. BALF dilutions were 1:2 for CysLTs and LTB 4 . BALF was undiluted for IFN- $\gamma$. Serum was undiluted for GM-CSF. All EIA assays were performed according to the manufacturer's instructions.

\subsection{Statistical Analysis}

Data are expressed as the mean \pm standard deviation. Comparisons between the groups were made using a one-way analysis of variance. Calculations were performed using GraphPad Prism (ver. 5.02; GraphPad Software, San Diego, CA, USA). A $p$-value of $<0.05$ was considered statistically significant.

\section{Results}

\subsection{Cell Counts in BALF}

Df/Df mice had a significantly increased BALF total cell count compared with control NS/NS mice $(p<0.05)$. Mice co-sensitized using AD particles and Df (AD + Df/Df mice) had greater enhancement of airway inflammation compared with Df/Df mice, and the total cell count was significantly increased (11.2-fold) in AD + Df/Df mice (Figure 2). The increased cell count was consistent for macrophages, eosinophils, lymphocytes, and neutrophils in AD + Df/Df mice, as compared with Df/Df mice (Figure 2). The increased neutrophil count was most noticeable in the differential leukocyte count, with a significant (20.2-fold) elevation in AD + Df/Df mice, as compared with Df/Df mice. Prl treatment alone had no effect on cell counts in NS/NS and Df/Df control mice.
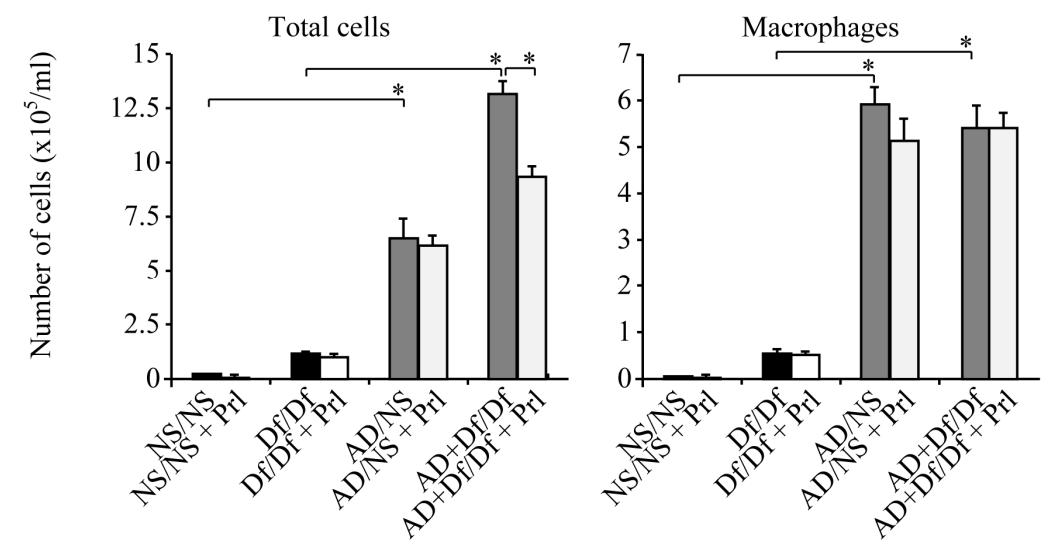

Figure 2. Cont. 

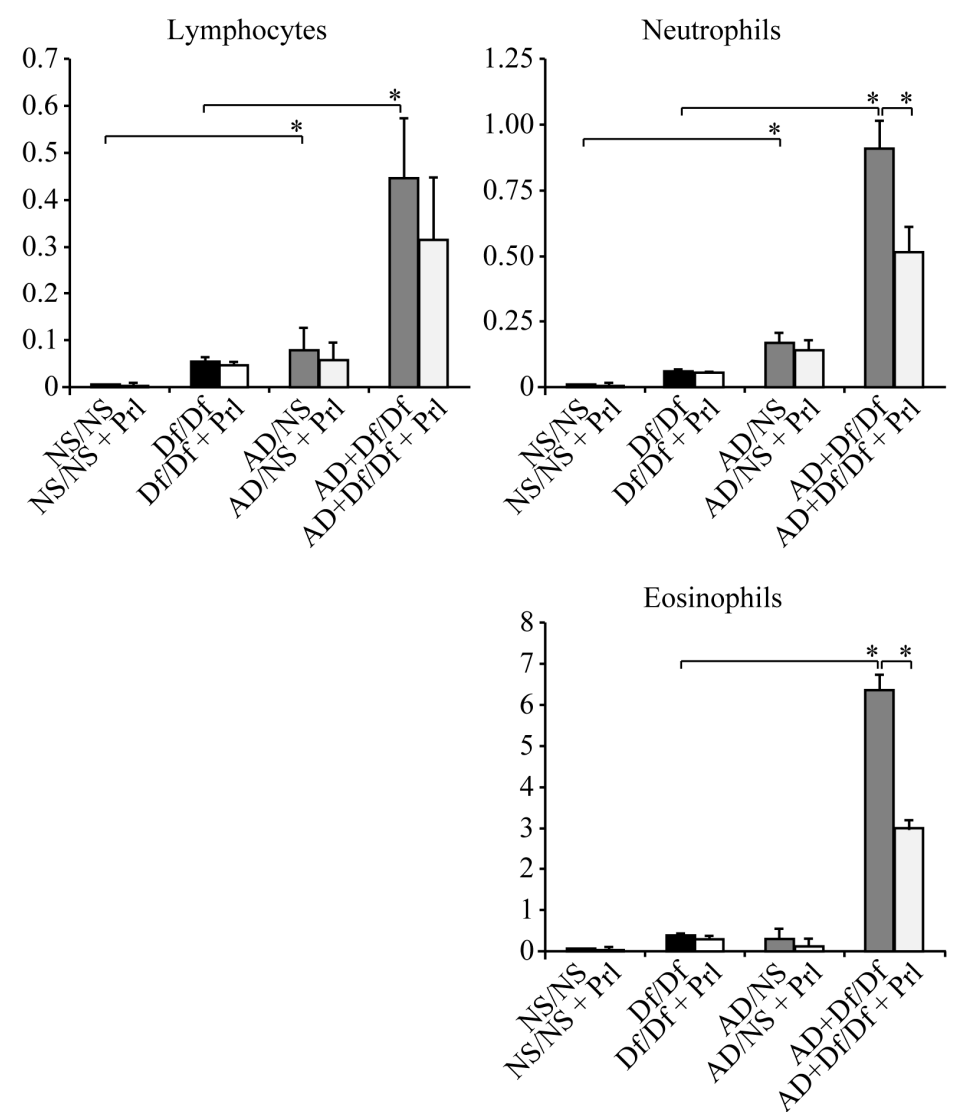

Figure 2. Total and differential leukocyte counts in bronchoalveolar lavage fluid (BALF). The cell counts in BALF were obtained $24 \mathrm{~h}$ after the allergen challenge on day 11 . The differential leukocyte counts included macrophages, lymphocytes, neutrophils, and eosinophils. Total cell counts in Asian dust (AD) + Dermatophagoides farina (Df)/Df + Pranlukast (Prl) mice were significantly decreased, as compared with $\mathrm{AD}+\mathrm{Df} / \mathrm{Df}$ mice. Data are expressed as the mean \pm standard deviation, with eight mice per group. ${ }^{*} p<0.05$.

Prl-treated mice co-sensitized using AD particles and Df (AD + Df/Df + Prl mice) exhibited a significantly decreased BALF total cell count, as compared with AD + Df/Df mice $(p<0.05$; Figure 2$)$. The total cell count was significantly decreased by $29.6 \%$ in AD + Df/Df + Prl mice. Prl treatment did not affect the total cell counts in AD/NS mice. The decreased cell counts were significant and consistent for eosinophils (52.4\%) and neutrophils (43.1\%) in AD + Df/Df + Prl mice, as compared with $\mathrm{AD}+\mathrm{Df} / \mathrm{Df}$ mice $(p<0.05$; Figure 2).

\subsection{Cytokine Profile of BALF}

Cytokine levels in BALF were measured to investigate the mechanisms through which Prl attenuates the allergic airway response induced by AD particles in the mouse model of Df-induced asthma. In parallel with the inflammatory cell recruitment in BALF, AD particles induced the production of several cytokines that are important in the development of asthma. The levels of T-helper 2 (Th2) cytokines (IL-5 and IL-13) in BALF from AD + Df/Df mice were significantly decreased by Prl treatment $(p<0.05$; Figure 3$)$, while the Th1 cytokine (IFN- $\gamma$ ) and inflammatory cytokines' (IL-6, MIP-2/CXCL2, and KC/CXCL1) levels were not significantly decreased after Prl treatment. 

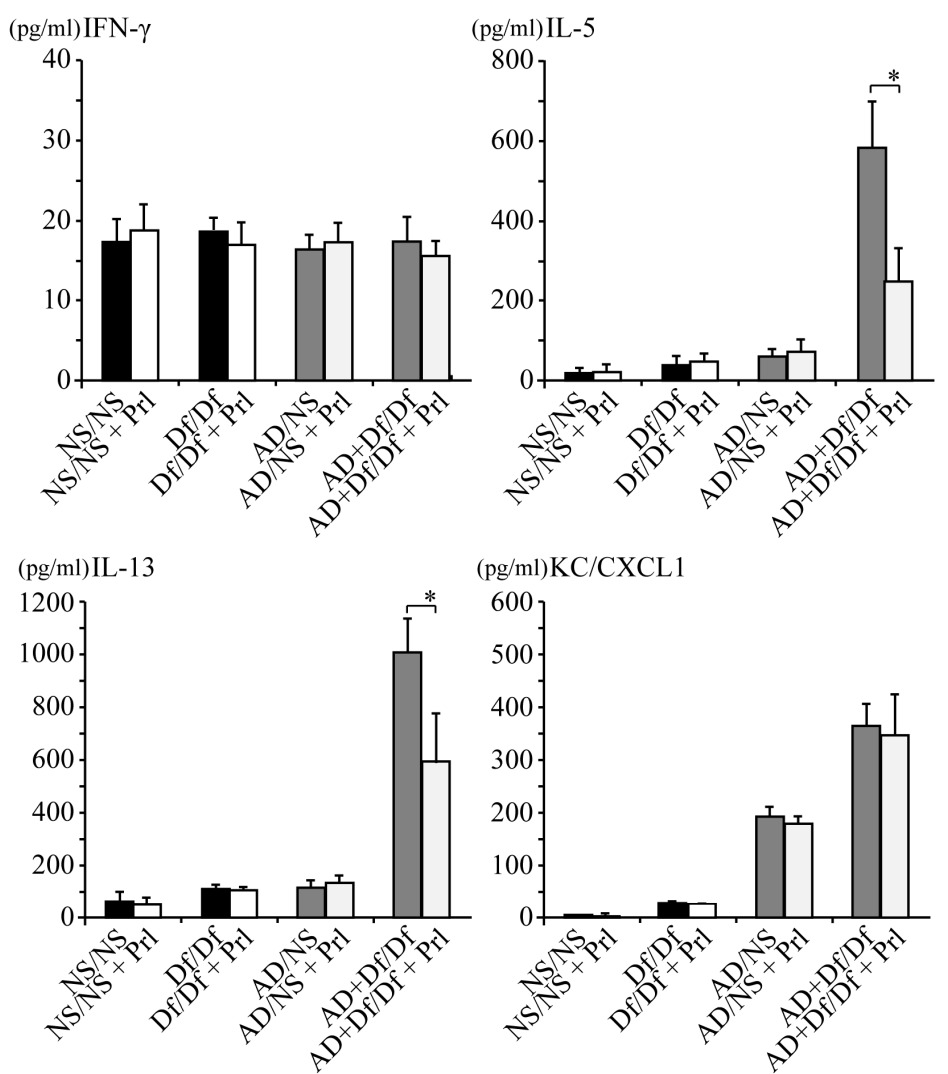

$(\mathrm{pg} / \mathrm{ml}) \mathrm{KC} / \mathrm{CXCL} 1$
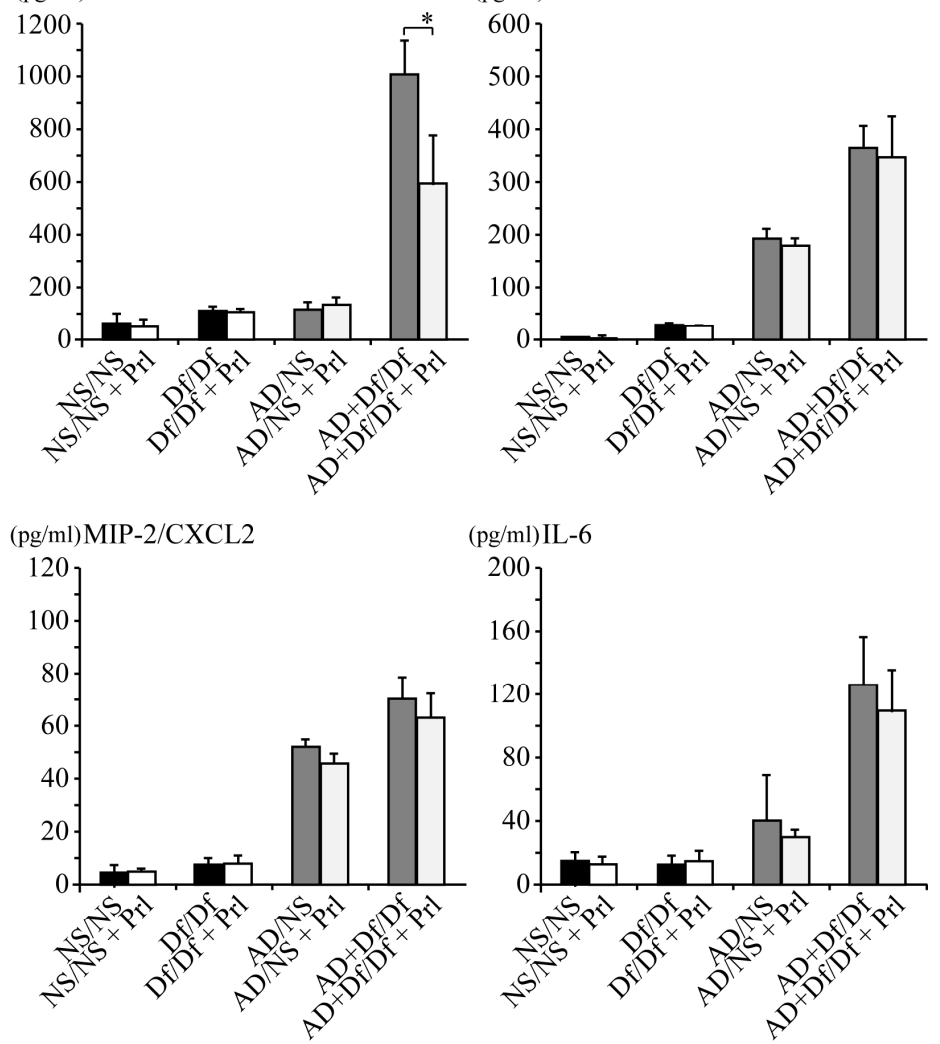

(pg/ml)IL-6

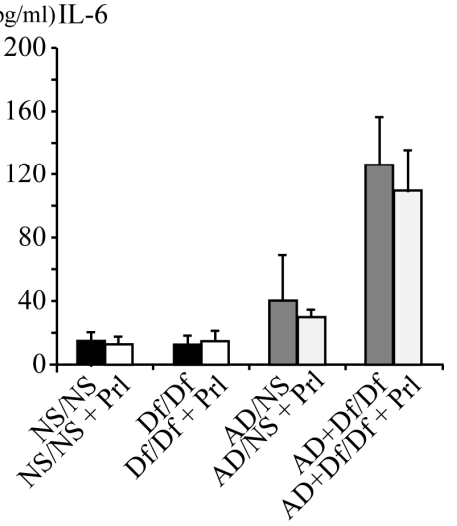

Figure 3. Cytokine and chemokine levels in bronchoalveolar lavage fluid (BALF). BALF cytokine and chemokine expression profiles were analyzed using enzyme immunoassays for interferon (IFN)- $\gamma$, interleukin (IL)-5, IL-13, keratinocyte-derived chemokine (KC/CXCL1), macrophage inflammatory protein-2 (MIP-2/CXCL2), and IL-6. Data for each group are expressed as the mean \pm standard deviation, with six mice per group. ${ }^{*} p<0.05$.

\subsection{Histopathological Changes in the Lung}

Lung specimens were evaluated using H\&E staining to determine the histopathological effects of Prl treatment on the airway. Df/Df mice had greater peribronchiolar and perivascular inflammatory cell infiltration, as compared with control NS/NS mice. Greater airway inflammation was also apparent in $\mathrm{AD}+\mathrm{Df} / \mathrm{Df}$ mice, as compared with Df/Df mice (Figure 4). AD + Df/Df + Prl mice exhibited relatively weak inflammatory responses, as compared with $\mathrm{AD}+\mathrm{Df} / \mathrm{Df}$ mice. These histopathological findings were consistent with the BALF analyses that revealed significant decreases in eosinophil and neutrophil counts after Prl treatment. 


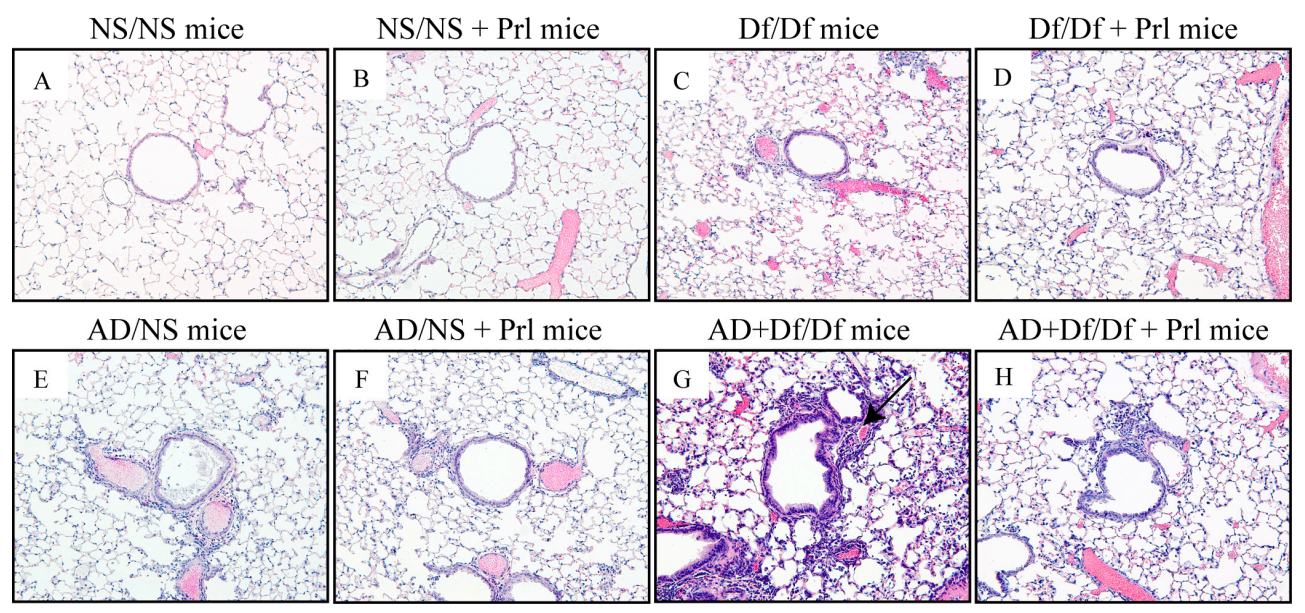

Figure 4. Effects of Pranlukast (Prl) treatment on histopathological changes in the lungs. Light photomicrographs of representative lung sections were stained using hematoxylin and eosin (magnification: $\times 200)$. Representative light photomicrographs of normal saline (NS)/NS mice (A); NS/NS + Prl mice (B); Dermatophagoides farina (Df)/Df mice (C); Df/Df + Prl mice (D); Asian dust (AD) / NS mice (E); AD/NS + Prl mice (F); AD + Df/Df mice (G); and AD + Df/Df + Prl mice (H). Arrow heads show peribronchiolar and perivascular mixed inflammatory cell infiltration in AD + Df/Df mice.

\subsection{Measurements of CysLTs and $L_{T B} B_{4}$ in BALF}

$\mathrm{AD}+\mathrm{Df} / \mathrm{Df}$ and Df/Df mice exhibited higher CysLT levels in BALF as compared with AD/NS and NS/NS mice. Furthermore, AD + Df/Df mice exhibited higher levels of CysLT compared with $\mathrm{Df} / \mathrm{Df}$ mice. The increased CysLTs levels in AD + Df/Df and Df/Df mice were significantly reduced by Prl treatment. CysLTs levels in AD + Df/Df + Prl mice were 52.2\% lower than those in Df/Df + Prl mice $\left(p<0.05\right.$; Figure 5A). Similarly, AD + Df/Df mice exhibited significantly higher $\mathrm{LTB}_{4}$ levels as compared with Df/Df mice ( $p<0.05$; Figure 5B). Prl treatment also significantly decreased $\mathrm{LTB}_{4}$ levels in BALF $(p<0.05$; Figure 5 B).
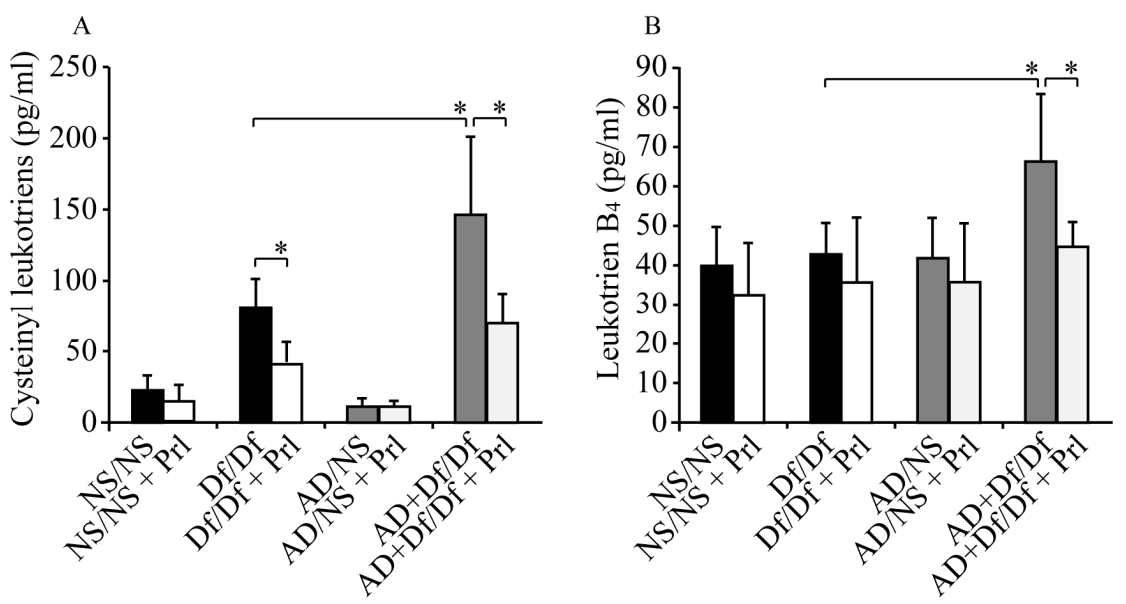

Figure 5. Effects of Pranlukast (Prl) treatment on cysteinyl leukotrienes (CysLTs) and dihydroxy-LT $\left(\mathrm{LTB}_{4}\right)$ levels in bronchoalveolar lavage fluid (BALF). BALF LT production was measured using enzyme immunoassays for CysLTs $(\mathbf{A})$ and $\mathrm{LTB}_{4}(\mathbf{B})$. Data for each group are expressed as the mean \pm standard deviation, with six mice per group. ${ }^{*} p<0.05$. 


\subsection{Measurement of GM-CSF in Serum and BALF}

GM-CSF levels in serum and BALF were measured to investigate the mechanisms underlying the decreased BALF values for neutrophils and $\mathrm{LTB}_{4}$ following treatment with Prl. GM-CSF levels were not significantly decreased after Prl treatment (Figure 6).
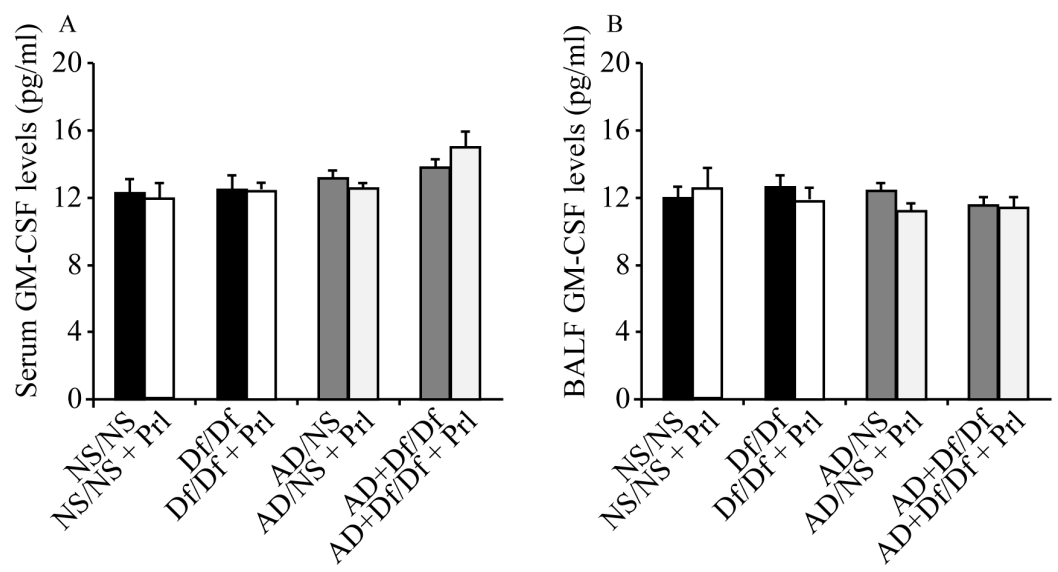

Figure 6. Granulocyte-macrophage colony stimulating factor (GM-CSF) levels in serum and bronchoalveolar lavage fluid (BALF). GM-CSF levels in serum (A) and BALF (B) were analyzed using enzyme immunoassays. Data for each group are expressed as the mean \pm standard deviation, with six mice per group.

\section{Discussion}

The present study revealed that AD particles can augment airway inflammation in a Df-sensitized mouse model of asthma. The data also revealed significant increases in the number of total cells, neutrophils, and eosinophils in BALF. AD particles also increased the production of CysLTs, $\mathrm{LTB}_{4}$, and Th2 cytokines (IL-5 and IL-13). However, the CysLT 1 receptor antagonist (Prl) significantly reduced the numbers of eosinophils and neutrophils in BALF and decreased the production of Th2 cytokines (IL-5 and IL-13), CysLTs, and $\mathrm{LTB}_{4}$. These data suggested that AD particles can influence the early stage of antigen-induced immune responses of asthma to an allergen. Furthermore, a CysLT 1 receptor antagonist may be beneficial to suppress the initial AD-augmented immune response.

Several epidemiological studies have suggested that AD emissions can aggravate asthma, with resulting increases in hospitalization and emergency room visits, deterioration of pulmonary function, and respiratory symptoms [9-15]. The objectives of these studies were to investigate the association between short-term exposure to heavy $\mathrm{AD}$ and asthma, although the effects of long-term exposure to $\mathrm{AD}$ on the development of asthma are not clearly understood. The present study showed that co-exposure to $\mathrm{AD}$ particles in the antigen sensitization phase of an asthma mouse model was able to increase eosinophilic and neutrophilic airway inflammation. Therefore, long-term exposure to AD may be a risk factor for the development of asthma.

Asthma is a phenotypically heterogeneous chronic disease of the airways, characterized by either predominant eosinophilic or neutrophilic, or even mixed eosinophilic/neutrophilic, inflammatory patterns. Neutrophils play an important role in the pathogenesis of severe asthma [29]. Exposure of patients with asthma to airborne PM can increase their IL-8 concentrations in BALF and blood, as well as IL-8 mRNA expression in bronchial biopsy tissue [30,31]. IL-8 is an important neutrophil chemotaxin in the lower respiratory tract [32], and several studies have demonstrated that neutrophils, but not eosinophils, migrate to the lungs of patients with asthma following PM exposure [33,34]. Therefore, airborne PM can augment neutrophilic airway inflammation in asthma. Similarly, the present study showed that, in the early stage of an antigen-induced immune response, AD particles can increase the number of neutrophils, the concentration of MIP-2/CXCL2 (a murine homologue of IL-8), and the 
concentration of $\mathrm{LTB}_{4}$ in the setting of co-exposure to AD particles and antigen in BALF. $\mathrm{LTB}_{4}$ is mainly generated by neutrophils and stimulates neutrophil chemotaxins and activation of the cells $[35,36]$. As a result, the number and percentage of neutrophils were increased in the mouse airways and lungs. Therefore, exposure to AD during the development asthma may be a risk factor for an increased asthma severity.

CysLT $_{1}$ receptor antagonists are potent and selective antagonists of CysLT activity. However, in the present study, Prl significantly reduced the number of eosinophils and neutrophils in BALF and the concentration of $\mathrm{LTB}_{4}$. Previous reports have revealed beneficial therapeutic effects of CysLT receptor antagonists on neutrophilic inflammatory diseases, including chronic obstructive pulmonary disease, pulmonary fibrosis, and atherosclerosis [37-41]. Shimbori et al. reported that a CysLT receptor antagonist attenuated $\mathrm{LTB}_{4}$ levels in BALF [41]. In addition, Ramires et al. reported that a CysLT 1 receptor antagonist was able to inhibit 5-lipoxygenase activity and synthesis of $\mathrm{LTB}_{4}$ by activated neutrophils [42]. Thus, $\mathrm{CysLT}_{1}$ receptor antagonists may have useful effects on neutrophilic airway inflammation augmented by AD particles, as well as on eosinophilic airway inflammation.

GM-CSF is an important chemoattractant for eosinophils and neutrophils, and can potentiate their differentiation and survival [43-45]. Th2 cells produce type II cytokines (e.g., IL-5 and IL-13) and eosinophils can produce GM-CSF. Thus, we hypothesize that the decreased neutrophil and $\mathrm{LTB}_{4}$ values after Prl treatment may have been dependent on decreased GM-CSF production from Th2 cells and eosinophils, as Prl reduced the number of Th2 cells and eosinophils. However, we did not detect a significant difference in GM-CSF production with and without Prl treatment.

There are several limitations in this study. First, we did not analyze the detailed composition of the $\mathrm{AD}$ particles. AD particles mainly consist of mineral dust originating from geological substances, such as silicon dioxide, aluminum oxide, iron (III) oxide, calcium oxide, magnesium oxide [46], anthropogenic metals, and chemicals, although microorganisms that have been introduced by rapid industrial development can also attach to AD particles [47,48]. Thus, the present study was unable to determine which component(s) of AD particles had the strongest effect(s) on augmenting airway inflammation. As noted earlier, urban airborne PM augments asthma, which is primarily dependent on neutrophilic airway inflammation [33,34]. Thus, it is possible that anthropogenic substances attached to AD particles, rather than geological substances, augmented the neutrophilic airway inflammation in the present study. Second, a previous study revealed significant increases in airway hyper-responsiveness (AHR) after intranasal Df administration in the same mouse model [28], although we did not evaluate AHR or pulmonary function in the present study, as we were unable to collect a sufficient amount of AD particles. Third, human patients with asthma are a heterogeneous population, and asthma is affected by unique interactions between genetic and environmental factors. Therefore, the usefulness of Prl as a therapeutic agent to control airway inflammation and bronchoconstriction augmented by AD exposure may vary among individuals.

\section{Conclusions}

The present study demonstrated that co-exposure to AD particles and antigen during the sensitization phase of a mouse model of asthma augmented neutrophilic and eosinophilic airway inflammation, as demonstrated by increased levels of CysLTs and $\mathrm{LTB}_{4}$, which could be attenuated by the $\mathrm{CysLT}_{1}$ receptor antagonist $(\mathrm{Prl})$.

Acknowledgments: This research was supported by the Environment Research and Technology Development Fund (5-1453) of the Japanese Ministry of the Environment.

Author Contributions: Jun Kurai, Masanari Watanabe, Hiroyuki Sano, Degejirihu Hantan, Yuji Tohda, and Eiji Shimizu conceived and designed the experiments. Jun Kurai, Masanari Watanabe and Degejirihu Hantan performed the experiments. Jun Kurai and Masanari Watanabe performed the analysis. Jun Kurai and Masanari Watanabe drafted the manuscript. All authors provided final approval of the version of the manuscript for publication. All authors had full access to all data in the study and take full responsibility for the integrity of all data and the accuracy of the data analysis.

Conflicts of Interest: The authors declare no conflict of interest. 


\section{Abbreviations}

The following abbreviations are used in this manuscript:

$\begin{array}{ll}\text { AD } & \text { Asian dust } \\ \text { BALF } & \text { bronchoalveolar lavage fluid } \\ \text { CMC } & \text { carboxymethylcellulose sodium } \\ \text { CysLT } & \text { type } 1 \text { cysteinyl leukotriene } \\ \text { Df } & \begin{array}{l}\text { Dermatophagoides farina } \\ \text { enzyme immunoassay }\end{array} \\ \text { EIA } & \text { Granulocyte-macrophage colony stimulating factor } \\ \text { GM-CSF } & \text { hematoxylin and eosin } \\ \text { H\&E } & \text { interferon } \\ \text { IFN } & \text { interleukin } \\ \text { IL } & \text { leukotriene } \\ \text { LT } & \text { Dihydroxy-LT } \\ \text { LTB } & \text { normal saline } \\ \text { NS } & \text { particulate matter } \\ \text { PM } & \text { Pranlukast } \\ \text { PRL } & \text { standard deviation } \\ \text { SD } & \end{array}$

\section{References}

1. Dockery, D.W.; Pope, C.A.; Xu, X.; Spengler, J.D.; Ware, J.H.; Fay, M.E.; Ferris, B.G., Jr.; Speizer, F.E. An association between air pollution and mortality in six U.S. Cities. N. Engl. J. Med. 1993, 329, 1753-1759. [CrossRef] [PubMed]

2. Ware, J.H.; Thibodeau, L.A.; Speizer, F.E.; Colome, S.; Ferris, B.G., Jr. Assessment of the health effects of atmospheric sulfur oxides and particulate matter: Evidence from observational studies. Environ. Health Perspect. 1981, 41, 255-276. [CrossRef] [PubMed]

3. Goudie, A.S. Desert dust and human health disorders. Environ. Int. 2014, 63, 101-113. [CrossRef] [PubMed]

4. Zhu, A.; Ramanathan, V.; Li, F.; Kim, D. Dust plumes over the Pacific, Indian, and Atlantic Oceans: Climatology and radiative impact. J. Geophys. Res.-Atmos. 2007. [CrossRef]

5. Tanaka, T.Y.; Chiba, M. A numerical study of the contributions of dust source regions to the global dust budget. Glob. Planet Chang. 2006, 52, 88-104. [CrossRef]

6. Sugimoto, N.; Lee, C.H. Characteristics of dust aerosols inferred from lidar depolarization measurements at two wavelengths. Appl. Opt. 2006, 45, 7468-7474. [CrossRef] [PubMed]

7. Sugimoto, N.; Matsui, I.; Shimizu, A.; Nishizawa, T.; Hara, Y.; Xie, C.; Uno, I.; Yumimoto, K.; Wang, Z.; Yoon, S. Lidar network observations of tropospheric aerosols. Proc. SPIE 2008. [CrossRef]

8. Hashizume, M.; Ueda, K.; Nishiwaki, Y.; Michikawa, T.; Onozuka, D. Health effects of asian dust events: A review of the literature. Nihon Eiseigaku Zasshi 2010, 65, 413-421. [CrossRef] [PubMed]

9. Watanabe, M.; Igishi, T.; Burioka, N.; Yamasaki, A.; Kurai, J.; Takeuchi, H.; Sako, T.; Yoshida, A.; Yoneda, K.; Fukuoka, Y.; et al. Pollen augments the influence of desert dust on symptoms of adult asthma patients. Allergol. Int. 2011, 60, 517-524. [CrossRef] [PubMed]

10. Watanabe, M.; Yamasaki, A.; Burioka, N.; Kurai, J.; Yoneda, K.; Yoshida, A.; Igishi, T.; Fukuoka, Y.; Nakamoto, M.; Takeuchi, H.; et al. Correlation between asian dust storms and worsening asthma in western Japan. Allergol. Int. 2011, 60, 267-275. [CrossRef] [PubMed]

11. Watanabe, M.; Kurai, J.; Tomita, K.; Sano, H.; Abe, S.; Saito, R.; Minato, S.; Igishi, T.; Burioka, N.; Sako, T.; et al. Effects on asthma and induction of interleukin- 8 caused by Asian dust particles collected in western Japan. J. Asthma 2014, 6, 595-602. [CrossRef] [PubMed]

12. Watanabe, M.; Noma, H.; Kurai, J.; Sano, H.; Saito, R.; Abe, S.; Kimura, Y.; Aiba, S.; Oshimura, M.; Yamasaki, A.; et al. Decreased pulmonary function in school children in western Japan after exposures to Asian desert dusts and its association with interleukin-8. BioMed Res. Int. 2015, 2015, 583293. [CrossRef] [PubMed]

13. Kanatani, K.T.; Ito, I.; Al-Delaimy, W.K.; Adachi, Y.; Mathews, W.C.; Ramsdell, J.W. Desert dust exposure is associated with increased risk of asthma hospitalization in children. Am. J. Respir. Crit. Care Med. 2010, 182, 1475-1481. [CrossRef] [PubMed]

14. Ueda, K.; Nitta, H.; Odajima, H. The effects of weather, air pollutants, and Asian dust on hospitalization for asthma in Fukuoka. Environ. Health Prev. Med. 2010, 15, 350-357. [CrossRef] [PubMed] 
15. Yoo, Y.; Choung, J.T.; Yu, J.; Kim do, K.; Koh, Y.Y. Acute effects of asian dust events on respiratory symptoms and peak expiratory flow in children with mild asthma. J. Korean Med. Sci. 2008, 23, 66-71. [CrossRef] [PubMed]

16. Gehring, U.; Wijga, A.H.; Hoek, G.; Bellander, T.; Berdel, D.; Bruske, I.; Fuertes, E.; Gruzieva, O.; Heinrich, J.; Hoffmann, B.; et al. Exposure to air pollution and development of asthma and rhinoconjunctivitis throughout childhood and adolescence: A population-based birth cohort study. Lancet Respir. Med. 2015, 3, 933-942. [CrossRef]

17. Gehring, U.; Wijga, A.H.; Brauer, M.; Fischer, P.; de Jongste, J.C.; Kerkhof, M.; Oldenwening, M.; Smit, H.A.; Brunekreef, B. Traffic-related air pollution and the development of asthma and allergies during the first 8 years of life. Am. J. Respir. Crit. Care Med. 2010, 181, 596-603. [CrossRef] [PubMed]

18. Salmon, J.A.; Higgs, G.A. Prostaglandins and leukotrienes as inflammatory mediators. Br. Med. Bull. 1987, 43, 285-296. [PubMed]

19. Peters-Golden, M.; Henderson, W.R., Jr. Leukotrienes. N. Engl. J. Med. 2007, 357, 1841-1854. [CrossRef] [PubMed]

20. Brink, C.; Dahlen, S.E.; Drazen, J.; Evans, J.F.; Hay, D.W.; Nicosia, S.; Serhan, C.N.; Shimizu, T.; Yokomizo, T. International Union of Pharmacology XXXVII. Nomenclature for leukotriene and lipoxin receptors. Pharmacol. Rev. 2003, 55, 195-227. [CrossRef] [PubMed]

21. Hicks, A.; Monkarsh, S.P.; Hoffman, A.F.; Goodnow, R., Jr. Leukotriene b4 receptor antagonists as therapeutics for inflammatory disease: Preclinical and clinical developments. Expert Opin. Investig. Drugs 2007, 16, 1909-1920. [CrossRef] [PubMed]

22. Miyahara, N.; Miyahara, S.; Takeda, K.; Gelfand, E.W. Role of the LTB4/BLT1 pathway in allergen-induced airway hyperresponsiveness and inflammation. Allergol. Int. 2006, 55, 91-97. [CrossRef] [PubMed]

23. Liu, M.; Yokomizo, T. The role of leukotrienes in allergic diseases. Allergol. Int. 2015, 64, 17-26. [CrossRef] [PubMed]

24. Hilberg, T.; Deigner, H.P.; Moller, E.; Claus, R.A.; Ruryk, A.; Glaser, D.; Landre, J.; Brunkhorst, F.M.; Reinhart, K.; Gabriel, H.H.; et al. Transcription in response to physical stress-Clues to the molecular mechanisms of exercise-induced asthma. FASEB J. 2005, 19, 1492-1494. [CrossRef] [PubMed]

25. Malireddy, S.; Lawson, C.; Steinhour, E.; Hart, J.; Kotha, S.R.; Patel, R.B.; Zhao, L.; Wilkins, J.R.; Marsh, C.B.; Magalang, U.J.; et al. Airborne agricultural particulate matter induces inflammatory cytokine secretion by respiratory epithelial cells: Mechanisms of regulation by eicosanoid lipid signal mediators. Indian J. Biochem. Biophys. 2013, 50, 387-401. [PubMed]

26. Ichinose, T.; Hiyoshi, K.; Yoshida, S.; Takano, H.; Inoue, K.; Nishikawa, M.; Mori, I.; Kawazato, H.; Yasuda, A.; Shibamoto, T. Asian sand dust aggravates allergic rhinitis in guinea pigs induced by Japanese cedar pollen. Inhal. Toxicol. 2009, 21, 985-993. [CrossRef] [PubMed]

27. Rabinovitch, N.; Strand, M.; Gelfand, E.W. Particulate levels are associated with early asthma worsening in children with persistent disease. Am. J. Respir. Crit. Care Med. 2006, 173, 1098-1105. [CrossRef] [PubMed]

28. Shibamori, M.; Ogino, K.; Kambayashi, Y.; Ishiyama, H. Intranasal mite allergen induces allergic asthma-like responses in NC/NGA mice. Life Sci. 2006, 78, 987-994. [CrossRef] [PubMed]

29. Nakagome, K.; Matsushita, S.; Nagata, M. Neutrophilic inflammation in severe asthma. Int. Arch. Allergy Immunol. 2012, 158 (Suppl. 1), 96-102. [CrossRef] [PubMed]

30. Holgate, S.T.; Sandstrom, T.; Frew, A.J.; Stenfors, N.; Nordenhall, C.; Salvi, S.; Blomberg, A.; Helleday, R.; Soderberg, M. Health effects of acute exposure to air pollution. Part I: Healthy and asthmatic subjects exposed to diesel exhaust. Res. Rep. Health Eff. Inst. 2003, 112, 1-30.

31. Bellido-Casado, J.; Plaza, V.; Perpina, M.; Picado, C.; Bardagi, S.; Martinez-Bru, C.; Torrejon, M. Inflammatory response of rapid onset asthma exacerbation. Arch. Bronconeumol. 2010, 46, 587-593. [CrossRef] [PubMed]

32. Kunkel, S.L.; Standiford, T.; Kasahara, K.; Strieter, R.M. Interleukin-8 (IL-8): The major neutrophil chemotactic factor in the lung. Exp. Lung Res. 1991, 17, 17-23. [CrossRef] [PubMed]

33. Sierra-Vargas, M.P.; Guzman-Grenfell, A.M.; Blanco-Jimenez, S.; Sepulveda-Sanchez, J.D.; Bernabe-Cabanillas, R.M.; Cardenas-Gonzalez, B.; Ceballos, G.; Hicks, J.J. Airborne particulate matter pm2.5 from mexico city affects the generation of reactive oxygen species by blood neutrophils from asthmatics: An in vitro approach. J. Occup. Med. Toxicol. 2009, 4, 17. [CrossRef] [PubMed] 
34. McCreanor, J.; Cullinan, P.; Nieuwenhuijsen, M.J.; Stewart-Evans, J.; Malliarou, E.; Jarup, L.; Harrington, R.; Svartengren, M.; Han, I.K.; Ohman-Strickland, P.; et al. Respiratory effects of exposure to diesel traffic in persons with asthma. N. Engl. J. Med. 2007, 357, 2348-2358. [CrossRef] [PubMed]

35. Busse, W.W. Leukotrienes and inflammation. Am. J. Respir. Crit. Care Med. 1998, 157, S210-S213. [CrossRef] [PubMed]

36. Martin, T.R.; Pistorese, B.P.; Chi, E.Y.; Goodman, R.B.; Matthay, M.A. Effects of leukotriene b4 in the human lung. Recruitment of neutrophils into the alveolar spaces without a change in protein permeability. J. Clin. Investig. 1989, 84, 1609-1619. [CrossRef] [PubMed]

37. Rubinstein, I.; Kumar, B.; Schriever, C. Long-term montelukast therapy in moderate to severe COPD-A preliminary observation. Respir. Med. 2004, 98, 134-138. [CrossRef] [PubMed]

38. Riccioni, G.; Bucciarelli, T.; Mancini, B.; Di Ilio, C.; D’Orazio, N. Antileukotriene drugs: Clinical application, effectiveness and safety. Curr. Med. Chem. 2007, 14, 1966-1977. [CrossRef] [PubMed]

39. Celik, P.; Sakar, A.; Havlucu, Y.; Yuksel, H.; Turkdogan, P.; Yorgancioglu, A. Short-term effects of montelukast in stable patients with moderate to severe copd. Respir. Med. 2005, 99, 444-450. [CrossRef] [PubMed]

40. Gueli, N.; Verrusio, W.; Linguanti, A.; De Santis, W.; Canitano, N.; Ippoliti, F.; Marigliano, V.; Cacciafesta, M. Montelukast therapy and psychological distress in chronic obstructive pulmonary disease (COPD): A preliminary report. Arch. Gerontol. Geriatr. 2011, 52, e36-e39. [CrossRef] [PubMed]

41. Shimbori, C.; Shiota, N.; Okunishi, H. Pranlukast, a cysteinyl leukotriene type 1 receptor antagonist, attenuates the progression but not the onset of silica-induced pulmonary fibrosis in mice. Int. Arch. Allergy Immunol. 2012, 158, 241-251. [CrossRef] [PubMed]

42. Ramires, R.; Caiaffa, M.F.; Tursi, A.; Haeggstrom, J.Z.; Macchia, L. Novel inhibitory effect on 5-lipoxygenase activity by the anti-asthma drug montelukast. Biochem. Biophys. Res. Commun. 2004, 324, 815-821. [CrossRef] [PubMed]

43. Levine, S.J. Bronchial epithelial cell-cytokine interactions in airway inflammation. J. Investig. Med. 1995, 43, 241-249. [PubMed]

44. Owen, W.F., Jr.; Rothenberg, M.E.; Silberstein, D.S.; Gasson, J.C.; Stevens, R.L.; Austen, K.F.; Soberman, R.J. Regulation of human eosinophil viability, density, and function by granulocyte/macrophage colony-stimulating factor in the presence of 3T3 fibroblasts. J. Exp. Med. 1987, 166, 129-141. [CrossRef] [PubMed]

45. Resnick, M.B.; Weller, P.F. Mechanisms of eosinophil recruitment. Am. J. Respir. Cell Mol. Biol. 1993, 8, 349-355. [CrossRef] [PubMed]

46. Zaady, E.; Offer, Z.Y.; Shachak, M. The content and contributions of deposited aeolian organic matter in a dry land ecosystem of the Negev Desert, Israel. Atmos. Environ. 2001, 35, 769-776. [CrossRef]

47. Hioki, T.; Nakanishi, S.; Mukai, H.; Murano, K.; Ohara, T.; Wakamatsu, S. Analysis of long-range transported and local air pollution with trace metal concentration ratio and lead isotope ratio in precipitation. J. Jpn. Soc. Atmos. Environ. 2008, 43, 100-111.

48. Wuebbles, D.J.; Lei, H.; Lin, J. Intercontinental transport of aerosols and photochemical oxidants from Asia and its consequences. Environ. Pollut. 2007, 150, 65-84. [CrossRef] [PubMed]

(C) 2016 by the authors; licensee MDPI, Basel, Switzerland. This article is an open access article distributed under the terms and conditions of the Creative Commons Attribution (CC-BY) license (http:/ / creativecommons.org/licenses/by/4.0/). 